\title{
PEMBUATAN GEOPOLIMER DARI METAKAOLIN DAN ABU TERBANG
}

\author{
Tjokorde Walmiki Samadhi*, Pambudi Pajar Pratama \\ Program Studi Teknik Kimia, Fakultas Teknologi Industri, Institut Teknologi Bandung \\ Jalan Ganesha 10, Bandung 40132 \\ Email: twsamadhi@che.itb.ac.id
}

\begin{abstract}
Abstrak
Geopolimer merupakan polimer anorganik yang tersusun oleh rantai-rantai atom $\mathrm{Al}, \mathrm{Si}$, dan 0 , dan dihasilkan melalui reaksi padatan aluminosilikat dengan aktivator basa kuat. Geopolimer dapat digunakan sebagai bahan perekat untuk konstruksi sebagai pengganti semen Portland. Reaksi geopolimerisasi dapat berlangsung di sekitar temperatur kamar, sehingga konsumsi energi produksi geopolimer lebih rendah daripada OPC. Berbagai limbah anorganik dapat digunakan sebagai reaktan aluminosilikat, sehingga geopolimer juga berguna dalam pengelolaan limbah padat. Kajian ini merupakan kelanjutan dari kajian awal yang membuktikan kelayakan teknis pemanfaatan bahan-bahan dalam negeri untuk sintesis geopolimer. Kajian ini mengevaluasi daya tahan geopolimer terhadap temperatur tinggi, yang mencerminkan kejadian kebakaran pada struktur bangunan sipil. Suatu percobaan faktorial $2^{4}$ dijalankan untuk mengevaluasi pengaruh jenis bahan aluminosilikat (metakaolin dan abu terbang), jenis aktivator basa $(\mathrm{NaOH}$ dan $\mathrm{KOH})$, temperatur pematangan mortar geopolimer $\left(60\right.$ dan $80{ }^{\circ} \mathrm{C}$ ), serta pemanasan pada $800{ }^{\circ} \mathrm{C}$ selama 2 jam terhadap kuat tekan mortar geopolimer. Kombinasi abu terbang, aktivator $\mathrm{KOH}$, serta temperatur pematangan 80 ${ }^{\circ} \mathrm{C}$ memberikan kuat tekan tertinggi, yang bahkan lebih tinggi daripada mortar OPC. Pemanasan pada $800{ }^{\circ} \mathrm{C}$ merusak struktur jaringan geopolimer metakaolin dengan mendorong kristalisasi yang mengkonsumsi fasa gel geopolimer, sementara justru memperkuat geopolimer abu terbang dengan meningkatkan kohesi antara partikel-partikel abu terbang.
\end{abstract}

Kata kunci: geopolimer, mortar, OPC, kuat tekan, daya tahan panas

\begin{abstract}
SYNTHESIS OF GEOPOLYMER FROM METAKAOLIN AND FLY ASH. Geopolymer is an inorganic polymer produced by reacting aluminosilicate solids with a strongly basic activator. Geopolymers can be applied as construction adhesives, replacing ordinary Portland cement. Geopolymerization reaction may occur near room temperatures, implying less energy consumption compared to Portland cement. A variety of inorganic wastes may be selected as the aluminosilicate reactant, which makes geopolymer useful in managing solid wastes. This study builds upon a previous preliminary study, which has proven the technical feasibility of using domestically available raw materials to produce geopolymers. This particular study evaluates the resistance of geopolymers to high temperature, which simulates fire in civil structures. A $2^{4}$ full factorial design experiment has been undertaken to evaluate the impact of aluminosilicate type (metakaolin and fly ash), base activator type $(\mathrm{NaOH}$ and $\mathrm{KOH}$ ), curing temperature (60 and $80{ }^{\circ} \mathrm{C}$ ), and heating at $800^{\circ} \mathrm{C}$ for 2 hours on the compressive strength of the mortar. Combining fly ash, $\mathrm{KOH}$, and higher curing temperature produces the highest compressive strength. Heating at $800{ }^{\circ} \mathrm{C}$ reduces the strength of metakaolin geopolymer by inducing crystallization which consumes the geopolymer gel phase, but improves the strength of the fly ash geopolymer mortar by increasing the cohesion of fly ash particles.
\end{abstract}

Keywords: geopolymer, mortar, OPC, compressive strength, heat resistance

*penulis korespondensi 


\section{PENDAHULUAN}

Selama satu dekade, pemanasan global telah menjadi topik permasalahan utama dalam berbagai penelitian sains dan rekayasa, yang terutama terkait dengan emisi gas buang seperti $\mathrm{CO}_{2}$ yang berasal dari aktivitas manusia. Sebanyak 65\% dari total emisi gas rumah kaca disumbangkan oleh $\mathrm{CO}_{2}$ (McCaffrey, 2002). Dari total emisi $\mathrm{CO}_{2}$ tersebut, sekitar $6 \%$ berasal dari industri semen, yang didominasi oleh produk ordinary Portland cement (OPC) sebagai bahan konstruksi yang dikenal secara luas oleh masyarakat. Produksi tiap ton semen Portland kira-kira akan melepaskan satu ton $\mathrm{CO}_{2}$ ke atmosfer (Davidovits, 1994b; McCaffrey, 2002). Dengan mengingat fungsi OPC sebagai bahan konstruksi yang digunakan di seluruh dunia dalam kuantitas sangat besar, maka upaya pengurangan emisi $\mathrm{CO}_{2}$ dari sektor industri ini sangat layak untuk diupayakan.

Geopolimer merupakan suatu polimer anorganik yang mulai dikembangkan pada dekade '80-an sebagai alternatif pengganti maupun pelengkap semen Portland dalam konstruksi sipil. Alur produksi geopolimer yang tidak memerlukan pengolahan pada temperatur tinggi menyebabkan bahan ini memiliki tapak kaki karbon (carbon footprint) yang jauh lebih kecil daripada semen Portland. Geopolimer disintesis dari bahanbahan yang mengandung silika dan alumina atau disebut aluminosilikat. Bahan baku aluminosilikat di Indonesia, seperti kaolin dan abu terbang mudah didapat. Hal inilah yang menyebabkan potensi pengembangan geopolimer di Indonesia sangat besar, apalagi jika dikaitkan dengan komitmen Indonesia untuk menurunkan emisi karbon nasional sebesar $26 \%$ pada tahun 2020 menurut kerangka kerja UNFCCC (Hilman, 2010).

Istilah 'geopolimer' pertama kali dikemukakan oleh Davidovits (1993) pada dasawarsa 1970an untuk mendeskripsikan suatu bahan padat dengan komposisi kimiawi yang menyerupai zeolit, namun secara struktural tersusun dari rantai makromolekul yang terdiri dari atom-atom silikon, aluminum, serta oksigen (Davidovits, 1993). Rantai makromolekul silika-aluminat ini melibatkan gugus-gugus poli(sialat), yang merupakan rantai dan cincin dari polimer antara $\mathrm{Si}^{4+}$ dengan $\mathrm{Al}^{3+}$ dalam ikatan koordinasi IV dengan oksigen yang berstruktur amorf hingga semi-kristalin, dengan persamaan empirik $M_{n}\left(-\left(\mathrm{SiO}_{2}\right)_{z}-\right.$
$\left.\mathrm{AlO}_{2}\right)_{n} \cdot \mathrm{wH}_{2} \mathrm{O}$ (Davidovits, 1994a). Dalam persamaan tersebut, ' $\mathrm{z}$ ' adalah 1,2 , atau 3 atau lebih sampai dengan 32 , M adalah kation monokovalen seperti $\mathrm{K}$ (Kalium) atau $\mathrm{Na}$ (Natrium) dan ' $\mathrm{n}$ ' adalah derajat polikondensasi. Ikatan poli(sialat) dalam geopolimer ini lebih lanjut dibedakan menjadi 3 tipe, yaitu poli(sialat) tipe (-Si-O-Al-O-), poli(sialat-silokso) tipe (-Si-O-Al-O-Si-O-), serta poli(sialat-disilokso) tipe (-Si-O-Al-O-SiO-Si-0-) (Davidovits, 1994a).

Geopolimer disintesa dari bahan dasar yang berupa senyawa aluminosilikat dengan aktivator yang berupa larutan alkali hidroksida dan(atau) alkali silikat. Pelarutan dari aluminosilikat oleh alkali akan menghasilkan monomer $\mathrm{Si}(\mathrm{OH})_{4}$ dan $\mathrm{Al}(\mathrm{OH})_{4}$ yang kemudian akan terpolikondensasi menjadi polimer alkali aluminosilikat yang memiliki struktur jaringan melalui pembentukan ikatan silang (crosslinking) 3dimensi (Davidovits, 1993).

Dalam konteks pengembangan proses berwawasan lingkungan, keunggulan geopolimer tidak hanya bertumpu pada konsumsi energi yang lebih rendah daripada OPC, tetapi juga pada fleksibilitas bahan baku yang sangat tinggi. Proses sintesis geopolimer praktis dapat memanfaatkan padatan aluminosilikat apapun, dari mineral alami, bahan sintetik, hingga limbah anorganik. Xu dan van Deventer (2003) menggolongkan bahan-bahan baku aluminosilikat ini sebagai: (1) bahan-bahan terkalsinasi, misalnya metakaolin, abu terbang, terak peleburan logam (slag), dan sebagainya, serta (2) bahanbahan tak terkalsinasi seperti mineral-mineral kaolinit, feldspar, limbah pengolahan bijih tambang (tailing), dan lain-lain.

Sebuah kajian awal yang telah dipublikasikan (Samadhi dan Pratama, 2013) telah membuktikan kelayakan teknis proses sintesis geopolimer dengan memanfaatkan bahan-bahan baku dari Indonesia, yakni kaolin Belitung dan abu terbang dari PLTU Paiton di Jawa Timur. Pembuktian ini didasarkan pada pembandingan karakteristik waktu ikat (setting time) awal dan akhir, serta kuat tekan (compressive strength) geopolimer dengan karakteristik OPC. Secara umum, kajian awal ini mengungkapkan bahwa geopolimer abu terbang menghasilkan waktu ikat yang lebih pendek daripada metakaolin, meskipun secara umum waktu ikat kedua jenis geopolimer tersebut masih lebih panjang daripada OPC. Penggunaan aktivator $\mathrm{KOH}$ 
menghasilkan waktu ikat yang lebih pendek dan kuat tekan yang lebih tinggi daripada $\mathrm{NaOH}$ untuk kedua jenis bahan baku aluminosilikat. Secara umum abu terbang lebih menjanjikan sebagai bahan baku geopolimer, karena mampu menghasilkan kuat tekan yang lebih tinggi daripada OPC, terutama jika dikombinasikan dengan aktivator KOH (Samadhi dan Pratama, 2013).

Tulisan ini memaparkan kelanjutan dari kajian awal di atas, dengan perhatian utama pada pengukuran pengaruh pemaparan temperatur tinggi terhadap kekuatan mekanik geopolimer. Ini merupakan aspek penting dalam aplikasi konstruksi, karena mencerminkan ketahanan bahan terhadap kejadian kebakaran. Konsisten dengan kajian sebelumnya, penggunaan bahan-bahan baku dari dalam negeri tetap diutamakan. Hal ini dimaksudkan untuk memaksimumkan manfaat dari kajian, yang mencakup tidak hanya pengurangan emisi gas rumah kaca dan penghematan energi, namun juga pemanfaatan bahan baku mineral serta limbah industri di dalam negeri.

\section{METODE}

\section{Persiapan dan Karakterisasi Bahan Baku}

Bahan-bahan baku utama pembentuk struktur jaringan geopolimer yang dipilih dalam penelitian ini mencakup kaolin, abu terbang, dan natrium silikat. Kaolin yang digunakan berasal dari kepulauan Bangka Belitung yang dieksplorasi oleh PT Dian Lestari Sejahtera di Kawasan Industri MM2100 di Cibitung. Abu terbang berkategori ASTM Class F berasal dari PLTU Paiton di Jawa Timur dan diadakan melalui CV Sumber Joyo di Malang. Natrium silikat yang dipilih berkualitas teknis, dan diperoleh dari pemasok bahan kimia umum di daerah Bandung. Bahan-bahan basa yang digunakan mencakup $\mathrm{KOH}$ dan $\mathrm{NaOH}$. Kedua bahan ini berupa padatan berkualitas reagen dan dibeli dari pemasok bahan-bahan kimia umum di Bandung, dengan kemurnian sebesar 97-98\% untuk $\mathrm{KOH}$ dan $90-95 \%$ untuk $\mathrm{NaOH}$. Tabel 1 meringkaskan komposisi oksida kaolin
Belitung dan abu terbang PLTU Paiton yang digunakan dalam kajian ini, yang diukur dengan teknik X-Ray fluorescence (XRF) di laboratorium Balai Besar Keramik Kementerian Perindustrian RI di Bandung. Data komposisi ini diperlukan untuk memperoleh perbandingan $\mathrm{Si} / \mathrm{Al}$ yang tepat dalam formulasi campuran bahan-bahan baku sintesis geopolimer.

Sebelum digunakan dalam reaksi sintesis geopolimer, kaolin dikalsinasi untuk memperoleh bahan metakaolin dengan komposisi yang dipaparkan oleh Davidovits (1999) sebagai komposisi 'Kandoxi'. Istilah ini mengacu kepada tiga fasa kristalin utama yang terkandung dalam metakaolin tersebut, yakni kaolinit, nacrite, serta dickite (diistilahkan dengan "KAolinite, Nacrite, Dickite OXide"). Sesuai dengan paparan oleh Davidovits (1999), kalsinasi dilaksanakan pada temperatur $750{ }^{\circ} \mathrm{C}$ selama 6 jam dalam sebuah tanur listrik. Pemaparan yang lebih rinci mengenai karakteristik bahan kaolin serta metakaolin yang digunakan dalam kajian ini dapat disimak dalam karya-karya terdahulu dari Penulis (Samadhi dkk., 2011).

\section{Percobaan Utama}

Pengaruh pemaparan terhadap temperatur tinggi yang menjadi perhatian utama dalam kajian ini dikombinasikan dengan tiga variabel sintesis yang menjadi perhatian utama dalam kajian terdahulu, yakni jenis bahan aluminosilikat, jenis aktivator basa, serta temperatur pematangan (curing) (Samadhi dan Pratama, 2013). Percobaan utama dirancang sebagai percobaan faktorial penuh 2-level dengan dua replikasi, dan dengan pengaturan variabelvariabel percobaan sebagai berikut:

- jenis bahan aluminosilikat - metakaolin dan abu terbang

- jenis aktivator basa - $\mathrm{KOH}$ dan $\mathrm{NaOH}$

- temperatur pematangan (curing) mortar geopolimer - 60 dan $80{ }^{\circ} \mathrm{C}$

- temperatur pemaparan - temperatur ruang dan $800^{\circ} \mathrm{C}$

Tabel 1. Hasil Analisis XRF Kaolin dan Abu Terbang (Samadhi dan Pratama, 2013)

\begin{tabular}{lrrrrrrr}
\hline & $\% \mathrm{SiO}_{2}$ & $\mathrm{NAl}_{2} \mathrm{O}_{3}$ & $\% \mathrm{Fe}_{2} \mathrm{O}_{3}$ & $\% \mathrm{CaO}$ & $\% \mathrm{MgO}$ & $\% \mathrm{Na}_{2} \mathrm{O}$ & $\% \mathrm{~K}_{2} \mathrm{O}$ \\
\hline Kaolin & 48,08 & 36,13 & 0,65 & 0,014 & 0,016 & 0,041 & 0,329 \\
Abu Terbang & 40,09 & 30,72 & 35,74 & 18,66 & 5,460 & 0,590 & 2,100 \\
\hline
\end{tabular}


Besaran luaran percobaan yang dipilih untuk mewakili karakteristik penting produk geopolimer sebagai bahan perekat konstruksi adalah kuat tekan mortar yang diukur dengan alat penekan uniaksial universal (universal uniaxial loading tester). Untuk lebih memahami kelakuan proses geopolimerisasi bahan-bahan baku yang dipilih dan kaitannya dengan pemaparan terhadap temperatur tinggi, dilakukan pula karakterisasi morfologi permukaan benda uji dengan metode mikroskop elektron pindaian (scanning electron microscope atau SEM). Benda uji untuk pengukuran kuat tekan berbentuk kubus dari mortar dengan ukuran $50 \mathrm{~mm}$ x 50 $\mathrm{mm}$ x $50 \mathrm{~mm}$. Untuk OPC, mortar dibuat berdasarkan metode ASTM C 109-80 yang mensyaratkan perbandingan berat semenpasir sebesar 0,36 dan air-semen sebesar 0,485. Mortar OPC ini dibuat sebagai pembanding pengukuran kuat tekan. Mortar semen geopolimer dibuat dengan perbandingan berat pasta geopolimer-pasir sebesar 0,74. Pasta geopolimer sendiri dibuat dengan cara mencampurkan padatan aluminosilikat ke dalam larutan basa yang telah disiapkan dengan konsentrasi $10 \mathrm{M}$. Campuran kemudian direaksikan dengan bantuan alat pengaduk planetari (planetary mixer) yang berputar pada kecepatan rendah. Untuk metakaolin, perbandingan massa aluminosilikat - larutan basa adalah sebesar 1,2 , sedangkan untuk abu terbang diperlukan perbandingan sebesar 2,8. Perbandingan massa padat-cair ini ditetapkan berdasarkan kebutuhan minimum larutan untuk

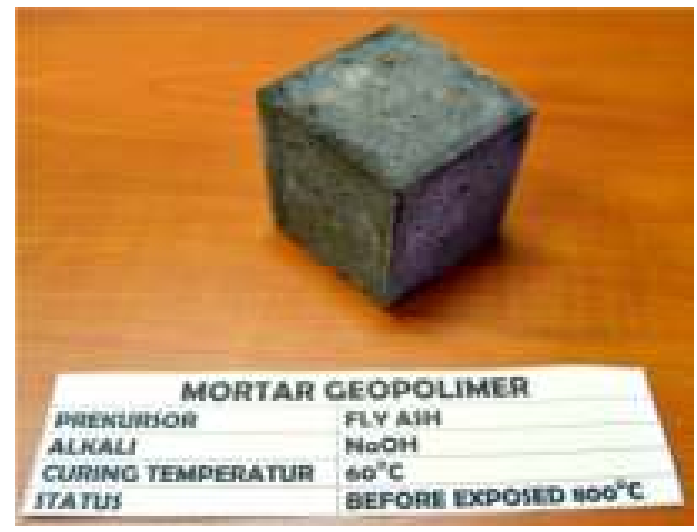

(a) menghasilkan konsistensi pasta geopolimer yang secara kualitatif memadai (homogen, tidak mengandung aglomerat makroskopik, serta dapat dituang ke dalam cetakan benda uji setelah dicampur dengan pasir untuk menghasilkan mortar). Benda-benda uji dimatangkan di dalam oven pengering selama 24 jam sebelum pengukuran kuat tekan.

Persiapan bahan-bahan baku dilaksanakan di Laboratorium Teknologi Mineral dan Bahan Anorganik Program Studi Teknik Kimia ITB, sementara sintesis dan pengujian sampel mortar dilaksanakan di Laboratorium Rekayasa Struktur Program Studi Teknik Sipil ITB. Karakterisasi morfologi permukaan sampel dilaksanakan dengan instrumen scanning electron microscope (SEM) di fasilitas gedung Basic Science A kampus ITB.

\section{HASIL DAN PEMBAHASAN \\ Percobaan Faktorial untuk Kuat Tekan Mortar}

Gambar 1 menyajikan tampilan visual contoh benda uji mortar geopolimer abu terbang dan metakaolin untuk pengukuran kuat tekan, yakni yang dihasilkan dengan menggunakan aktivator $\mathrm{NaOH}$ dan pematangan pada temperatur $60{ }^{\circ} \mathrm{C}$. Perbedaan warna kedua benda uji ini disebabkan oleh perbedaan warna masingmasing bahan baku aluminosilikat. Secara kualitatif, benda-benda uji mortar geopolimer yang telah dimatangkan memiliki integritas mekanik yang memadai untuk diuji kuat tekannya dengan alat penekan uniaksial.

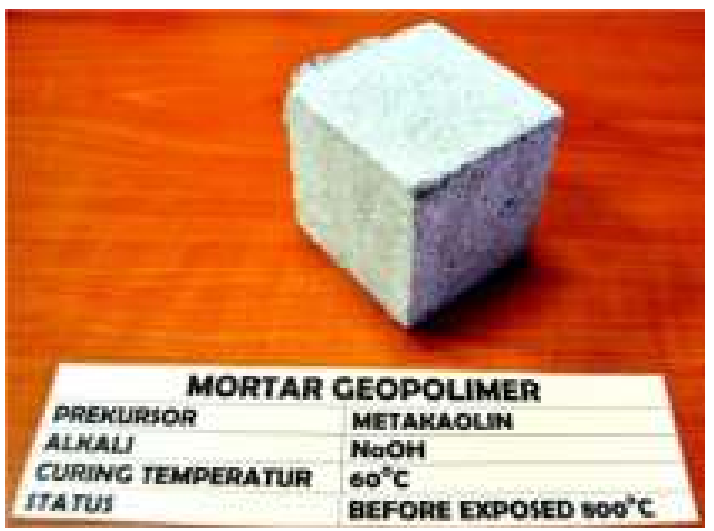

(b)

Gambar 1. Penampilan visual benda-benda uji kuat tekan mortar geopolimer (a) mortar geopolimer abu terbang dengan aktivator $\mathrm{NaOH}$ dan temperatur pematangan $60{ }^{\circ} \mathrm{C}$ (b) mortar geopolimer metakaolin dengan aktivator $\mathrm{NaOH}$ dan temperatur pematangan $60{ }^{\circ} \mathrm{C}$ 
Hasil-hasil pengukuran kuat tekan mortar geopolimer yang diperoleh dari percobaan utama yang dirancang sebagai percobaan faktorial penuh 4 faktor dengan 2level (percobaan faktorial $2^{4}$ ) dicantumkan secara lengkap dalam Tabel 2. Secara sekilas, ketelitian hasil pengukuran antara replikasi ke-1 dan ke-2 nampak baik. Hasil pengolahan data percobaan dengan metode ANOVA diringkaskan dalam Tabel 3, yang memuat identitas suku-suku dalam model linier yang menyatakan korelasi antara kuat tekan dengan suku-suku yang berupa efek tunggal (main effect) maupun interaksi, besaran efek dari setiap suku, serta nilai probabilitas statistik uji $\mathrm{F}_{0}$ dari setiap suku.
Nilai probabilitas statistik uji $\mathrm{F}_{0}$ (dinyatakan dengan notasi $P$-value dalam Tabel 3) suku-suku model empirik lebih rendah daripada tingkat keberartian yang umum dipilih dalam pengolahan data percobaan, yakni $\alpha=0,05$, kecuali untuk sukusuku berikut:

- interaksi 2-arah jenis aluminosilikat dengan temperatur pematangan

- interaksi 2 arah jenis basa dengan temperatur pematangan

- interaksi 2-arah temperatur pematangan dengan temperatur pemaparan

- semua interaksi 3-arah dan 4-arah

Tabel 2. Data Hasil Pengukuran Kuat Tekan Mortar dalam Percobaan Utama

\begin{tabular}{|c|c|c|c|c|c|c|}
\hline \multirow[b]{2}{*}{$\begin{array}{c}\text { Tempuhan } \\
\text { no. }\end{array}$} & \multirow{2}{*}{$\begin{array}{l}\text { Jenis } \\
\text { aluminosilikat }\end{array}$} & \multirow[b]{2}{*}{$\begin{array}{l}\text { Jenis } \\
\text { basa }\end{array}$} & \multirow{2}{*}{$\begin{array}{c}\mathrm{T} \\
\text { pematangan, } \\
{ }^{\circ} \mathrm{C}\end{array}$} & \multirow{2}{*}{$\begin{array}{c}\mathrm{T} \\
\text { pemaparan, } \\
{ }_{\mathrm{O}} \mathrm{C}\end{array}$} & \multicolumn{2}{|c|}{ Kuat tekan, $\mathrm{MPa}$} \\
\hline & & & & & Replikasi I & $\begin{array}{l}\text { Replikasi } \\
\text { II }\end{array}$ \\
\hline 1 & Metakaolin & $\mathrm{NaOH}$ & 60 & ruang & 10,29 & 8,43 \\
\hline 2 & Abu terbang & $\mathrm{NaOH}$ & 60 & ruang & 28,43 & 27,65 \\
\hline 3 & Metakaolin & $\mathrm{KOH}$ & 60 & ruang & 13,55 & 14,90 \\
\hline 4 & Abu terbang & $\mathrm{KOH}$ & 60 & ruang & 39,37 & 40,59 \\
\hline 5 & Metakaolin & $\mathrm{NaOH}$ & 80 & ruang & 14,12 & 13,82 \\
\hline 6 & Abu terbang & $\mathrm{NaOH}$ & 80 & ruang & 29,76 & 32,16 \\
\hline 7 & Metakaolin & $\mathrm{KOH}$ & 80 & ruang & 15,16 & 17,18 \\
\hline 8 & Abu terbang & $\mathrm{KOH}$ & 80 & ruang & 44,55 & 41,18 \\
\hline 9 & Metakaolin & $\mathrm{NaOH}$ & 60 & 800 & 2,45 & 2,15 \\
\hline 10 & Abu terbang & $\mathrm{NaOH}$ & 60 & 800 & 31,76 & 33,59 \\
\hline 11 & Metakaolin & $\mathrm{KOH}$ & 60 & 800 & 2,74 & 2,43 \\
\hline 12 & Abu terbang & $\mathrm{KOH}$ & 60 & 800 & 40,73 & 46,12 \\
\hline 13 & Metakaolin & $\mathrm{NaOH}$ & 80 & 800 & 2,94 & 3,14 \\
\hline 14 & Abu terbang & $\mathrm{NaOH}$ & 80 & 800 & 33,41 & 39,61 \\
\hline 15 & Metakaolin & $\mathrm{KOH}$ & 80 & 800 & 3,12 & 3,22 \\
\hline 16 & Abu terbang & $\mathrm{KOH}$ & 80 & 800 & 47,06 & 50,08 \\
\hline \multicolumn{3}{|c|}{ Pembanding: mortar OPC } & 60 & ruang & 30,00 & 29,22 \\
\hline \multicolumn{3}{|c|}{ Pembanding: mortar OPC } & 80 & ruang & 30,78 & 31,27 \\
\hline
\end{tabular}

Tabel 3. Hasil Pengolahan Data Percobaan Utama dengan metode ANOVA

\begin{tabular}{lrrr}
\hline \multicolumn{1}{c}{ Suku model } & Efek & $\begin{array}{c}\text { Koefisien } \\
\text { regresi }\end{array}$ & P-value \\
\hline Konstanta & & 22,990 & 0,000 \\
\hline Efek-efek tunggal (main effects): & & & \\
Jenis aluminosilikat & 29,776 & 14,888 & 0,000 \\
Jenis basa & 6,767 & 3,383 & 0,000 \\
T pematangan & 2,833 & 1,417 & 0,001 \\
T pemaparan & $-2,912$ & $-1,456$ & 0,000 \\
\hline Efek-efek interaksi: & & & \\
Aluminosilikat * Basa & 4,897 & 2,448 & 0,000 \\
Aluminosilikat ${ }^{*}$ T pematangan & 0,863 & 0,432 & 0,204 \\
Aluminosilikat ${ }^{*}$ T pemaparan & 7,746 & 3,873 & 0,000 \\
Basa T pematangan & $-0,193$ & $-0,097$ & 0,771 \\
Basa * T pemaparan & $-0,961$ & $-0,480$ & 0,160 \\
T pematangan * T pemaparan & $-0,257$ & $-0,128$ & 0,699 \\
Interaksi-interaksi 3-arah & & & $>0,100$ \\
\hline
\end{tabular}


Tidak ada kesulitan yang berarti dalam menginterpretasikan hasil pengolahan data percobaan di atas dengan metode ANOVA, karena perbedaan nilai probabilitas ( $P$-value) yang sangat besar antara suku-suku yang berarti secara statistik ( $P$-value $<0,05)$ dengan yang tidak berarti secara statistik $(P$ value $>0,05)$. Dengan kata lain, percobaan pengukuran kuat tekan geopolimer dengan melibatkan variasi temperatur pemaparan ini dapat dengan mudah menentukan variabelvariabel percobaan maupun efek-efek interaksi antar variabel yang mempengaruhi kuat tekan mortar geopolimer.

Nilai koefisien yang positif untuk efek tunggal jenis aluminosilikat menunjukkan bahwa peralihan dari metakaolin ke abu terbang meningkatkan kuat tekan. Pengamatan ini konsisten dengan hasil pada tulisan terdahulu yang tidak melibatkan pemaparan pada temperatur tinggi. Reaktivitas abu terbang diduga lebih tinggi daripada metakaolin, sehingga derajat pembentukan ikatan silang dalam geopolimer abu terbang lebih tinggi daripada dalam geopolimer metakaolin (Samadhi dan Pratama, 2013). Dibandingkan dengan OPC, geopolimer abu terbang menghasilkan mortar yang secara umum memiliki kuat tekan yang lebih tinggi, baik dengan menggunakan aktivator $\mathrm{NaOH}$ maupun $\mathrm{KOH}$. Namun demikian, seluruh sampel geopolimer metakaolin menghasilkan kuat tekan mortar yang jauh lebih rendah daripada OPC.

Koefisien efek tunggal jenis basa bernilai positif, yang menunjukkan bahwa peralihan dari $\mathrm{NaOH}$ ke $\mathrm{KOH}$ meningkatkan kuat tekan mortar geopolimer. Kekuatan basa $\mathrm{KOH}$ yang lebih tinggi daripada $\mathrm{NaOH}$ memungkinkan aktivator ini untuk bereaksi lebih cepat dengan padatan aluminosilikat (Phair dan van Deventer, 2001). Di samping keunggulan ini, jari-jari ionik $\mathrm{K}^{+}$yang lebih besar daripada $\mathrm{Na}^{+}$cenderung menyebabkan terbentuknya oligomer-oligomer silikat yang berukuran lebih besar dalam fasa gel geopolimer, yang meningkatkan derajat ikatan silang dalam produk geopolimer (Phair dan van Deventer, 2002).

Serupa dengan kedua efek tunggal di atas, efek tunggal temperatur pematangan juga memiliki koefisien yang bernilai positif. Hal ini menunjukkan bahwa peningkatan temperatur pematangan dari 60 ke $80{ }^{\circ} \mathrm{C}$ mampu meningkatkan derajat ikatan silang di dalam geopolimer, serta menuntaskan penguapan pelarut dari sampel geopolimer dalam periode waktu pematangan yang sama. Berlawanan dengan temperatur pematangan, efek tunggal temperatur pemaparan memiliki koefisien yang negatif. Data mentah pada Tabel 2 mengindikasikan bahwa penurunan kuat tekan karena pemaparan terhadap temperatur tinggi cenderung lebih dominan untuk geopolimer metakaolin.

Sebaliknya, data pada Tabel 2 mengisyaratkan bahwa pemaparan pada temperatur tinggi justru cenderung meningkatkan kuat tekan geopolimer abu terbang. Meski demikian, secara keseluruhan pengaruh penurunan kuat tekan mortar geopolimer metakaolin lebih dominan, sehingga hasil pengolahan data dengan metode ANOVA memberikan koefisien efek tunggal temperatur pemaparan yang negatif. Interaksi yang kuat antara pemaparan temperatur tinggi dengan jenis bahan baku aluminosilikat ini nampak pada nilai mutlak koefisien interaksi yang terbesar dibandingkan dengan interaksi-interaksi dua arah lainnya dalam Tabel 3. Pengaruh pemaparan temperatur tinggi terhadap geopolimer metakaolin dan abu terbang dijelaskan lebih lanjut berdasarkan pengamatan terhadap morfologi permukaan sampel kedua bahan tersebut.

\section{Pengaruh Pemanasan terhadap Morfologi Mortar Geopolimer}

Gambar 2.a. dan 2.b. menampilkan morfologi mortar geopolimer metakaolin dan abu terbang yang disintesis dengan aktivator $\mathrm{KOH}$ pada temperatur pematangan $80{ }^{\circ} \mathrm{C}$, sebelum mengalami pemaparan terhadap temperatur tinggi, yang diperoleh dengan metode SEM pada perbesaran 5000x. Morfologi mortar geopolimer metakaolin pada Gambar 2.a. menunjukkan bekas-bekas struktur berlapis dari partikel metakaolin, yang tertutup oleh fasa gel padat geopolimer sebagai hasil reaksi antara metakaolin dengan aktivator basa. Gambar 2.a. juga menunjukkan dengan jelas bahwa fasa gel padat ini berperan sebagai jembatan atau jejaring yang menghubungkan partikel-partikel metakaolin membentuk suatu struktur yang koheren. Morfologi mortar geopolimer metakaolin ini juga dicirikan dengan kehadiran pori-pori terbuka yang ekstensif. Morfologi mortar geopolimer abu terbang pada Gambar 2.b. 
menunjukkan kehadiran partikel cenosphere abu terbang, yakni partikel anorganik yang berwujud bola-bola berongga (Wang dkk., 2011). Salah satu butiran cenosphere dalam Gambar 2.b nampak telah bereaksi secara parsial. Fasa gel dalam mortar geopolimer abu terbang ini memiliki tesktur yang lebih kasar daripada geopolimer metakaolin. Berbeda dengan geopolimer metakaolin, morfologi geopolimer abu terbang tidak menunjukkan adanya jaringan pori-pori terbuka yang ekstensif.

$$
\text { Setelah pemaparan terhadap }
$$
temperatur $800{ }^{\circ} \mathrm{C}$ selama 2 jam, pengamatan visual menunjukkan terbentuknya retak-retak rambut berukuran makroskopik pada permukaan sampel mortar geopolimer metakaolin, seperti yang ditampilkan dalam Gambar 3. Retak-retak serupa tidak teramati pada sampel mortar geopolimer abu terbang. Hasil pengamatan morfologi permukaan dengan SEM ditampilkan pada Gambar 4.a. dan 4.b.

Perbandingan antara Gambar 2.a. dan 4.a. menunjukkan bahwa pemanasan pada $800{ }^{\circ} \mathrm{C}$ menyebabkan terjadinya proses kristalisasi pada fasa gel geopolimer metakaolin, dengan asumsi bahwa mineralmineral yang terkandung dalam pasir di dalam mortar kurang reaktif dibandingkan dengan fasa gel pada temperatur yang secara umum masih relatif rendah bagi kebanyakan reaksi fasa padat dalam keluarga bahan aluminosilikat. Terjadinya kristalisasi ini ditandai dengan terbentuknya bintik-bintik pada permukaan gel geopolimer yang semula bertekstur mulus.

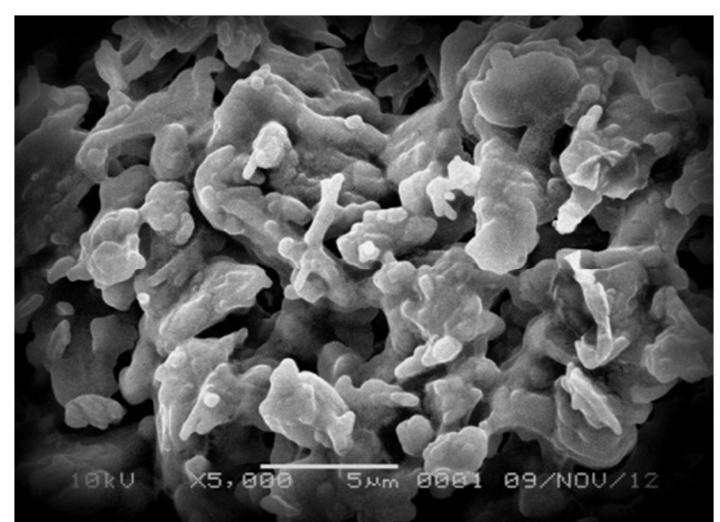

(a)

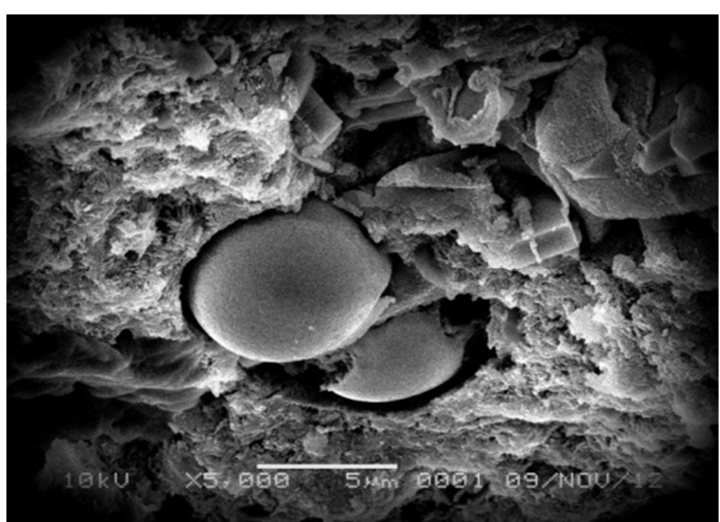

(b)

Gambar 2. Hasil analisis SEM mortar geopolimer dari (a) metakaolin dan (b) abu terbang yang menggunakan aktivator $\mathrm{KOH}$ dan temperatur pematangan $80^{\circ} \mathrm{C}$, sebelum pemaparan terhadap temperatur tinggi (Samadhi dan Pratama, 2013)

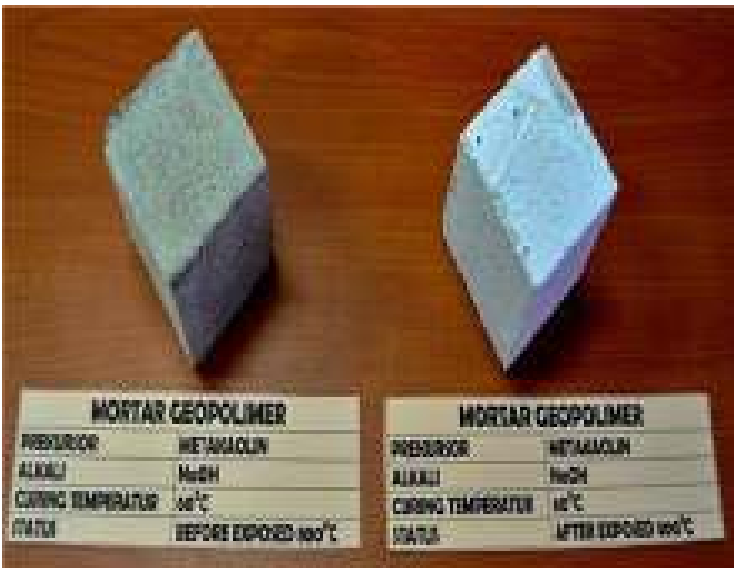

(a)

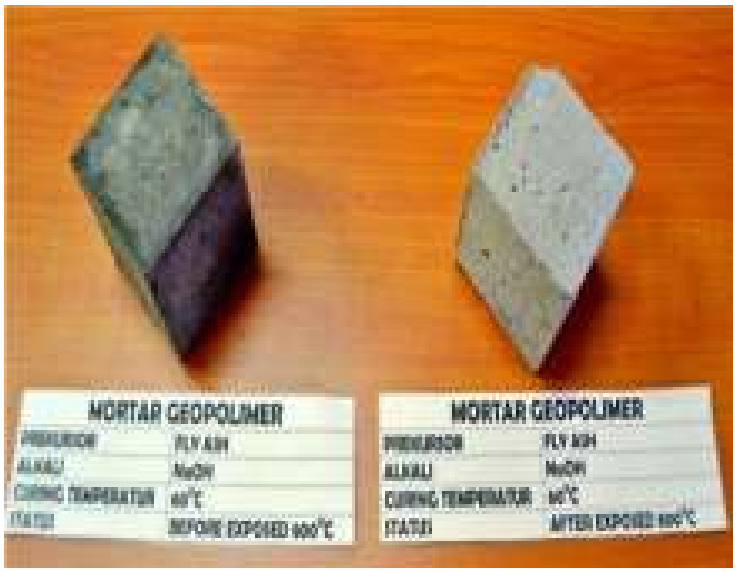

(b)

Gambar 3. Pengamatan visual sampel mortar sebelum dan setelah pemaparan terhadap temperatur $800^{\circ} \mathrm{C}$ untuk (a) metakaolin (b) abu terbang, dengan aktivator $\mathrm{NaOH}$ dan temperatur pematangan $60^{\circ} \mathrm{C}$; retak rambut teramati pada permukaan luar sampel mortar geopolimer metakaolin 


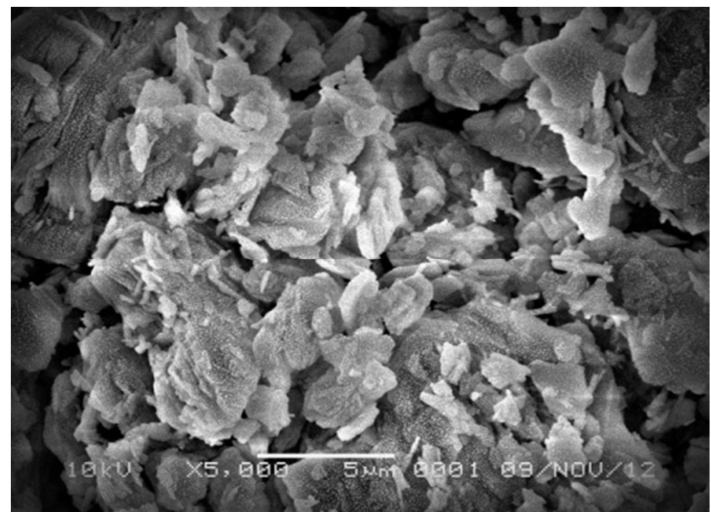

(a)

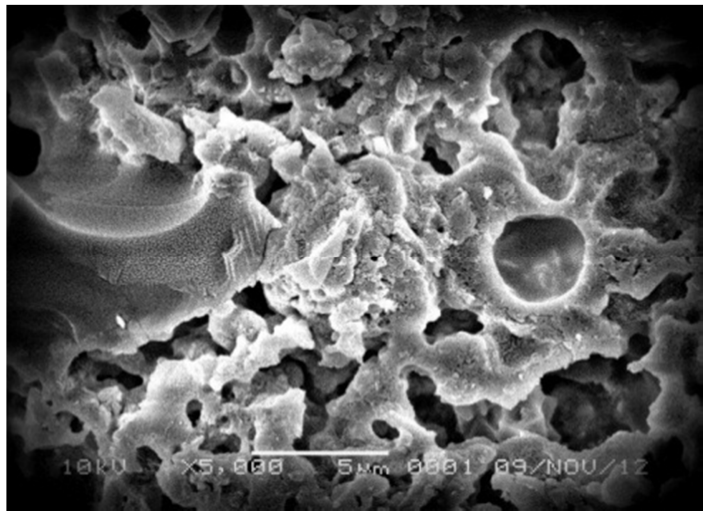

(b)

Gambar 4. Hasil analisis SEM mortar geopolimer dari (a) metakaolin dan (b) abu terbang yang menggunakan aktivator $\mathrm{KOH}$ dan temperatur pematangan $80^{\circ} \mathrm{C}$, setelah pemaparan terhadap temperatur $800{ }^{\circ} \mathrm{C}$ selama 2 jam

Selain itu, Gambar 4.a. menunjukkan pula terbentuknya fasa kristal yang berbentuk batang-batang pendek (teramati dengan jelas pada sudut kanan atas Gambar 4.a.). Geometri seperti demikian adalah ciri khas dari fasa mulit, yakni bahan aluminosilikat dengan rumus kimia teoritik $3 \mathrm{Al}_{2} \mathrm{O}_{3} \cdot 2 \mathrm{SiO}_{2}$. Pembentukan fasa mulit dari sisa-sisa metakaolin yang tidak terpolimerisasi juga dilaporkan oleh Barbosa dan MacKenzie (2003), namun pada rentang temperatur 1200-1300 ${ }^{\circ} \mathrm{C}$. Pada campuran reaksi geopolimer dengan kadar Na dan Si yang lebih tinggi, para peneliti ini juga mengamati pembentukan fasa kristalin nepheline $\left(\mathrm{NaAlSiO}_{4}\right)$ dari metakaolin yang tidak terpolimerisasi, pada temperatur $800{ }^{\circ} \mathrm{C}$.

Perubahan mikrostruktur lain yang teramati dengan jelas pada mortar geopolimer metakaolin adalah hilangnya fasa gel geopolimer yang semula membentuk jaringan 3-dimensi yang menjembatani partikelpartikel metakaolin. Reaksi kristalisasi yang menghasilkan mulit maupun fasa-fasa kristalin lainnya diduga mengkonsumsi fasa gel geopolimer ini, yang secara makroskopik muncul pula sebagai gejala terbentuknya retak-retak rambut pada permukaan benda uji setelah pemanasan. Sesuai dengan teori dasar mengenai sifat mekanik bahan getas seperti keramik dan gelas, kegagalan suatu benda getas sangat dipercepat oleh kehadiran cacatcacat, misalnya retakan-retakan pada permukaan benda, sebelum benda tersebut dikenai beban (Silva dan Thaumaturgo, 2003). Hal ini nampak jelas pada nilai-nilai kuat tekan mortar geopolimer metakaolin yang berkurang secara drastis setelah pemanasan pada $800{ }^{\circ} \mathrm{C}$, seperti tercantum dalam Tabel 2 .
Untuk mortar geopolimer abu terbang, pembandingan Gambar 2.b. dan 3.b. menunjukkan bahwa pemanasan pada temperatur $800{ }^{\circ} \mathrm{C}$ menyebabkan terjadinya peningkatan kohesi antar partikel-partikel di dalam sampel melalui penuntasan reaksi geopolimerisasi partikel-partikel abu terbang, yang menyisakan rongga-rongga berbentuk bola. Pada permukaan internal rongga-rongga ini dapat diamati zona reaksi pembentukan fasa gel, yang dicirikan oleh tekstur permukaan yang berbintik-bintik. Secara kualitatif, tidak teramati adanya perubahan morfologi jaringan pori-pori secara mencolok seperti yang teramati pada mortar geopolimer metakaolin.

Perbedaan respons geopolimer metakaolin dan abu terbang terhadap pemanasan pada $800{ }^{\circ} \mathrm{C}$ juga dilaporkan oleh Kong dkk. (2007). Para peneliti ini memaparkan hipotesis bahwa peningkatan kuat tekan geopolimer abu terbang dan penurunan kuat tekan geopolimer metakaolin diduga ditentukan oleh perbedaan struktur pori kedua bahan tersebut. Geopolimer abu terbang memiliki jaringan pori-pori halus yang tersebar merata di dalam sampel, yang memudahkan difusi uap air pada pemanasan. Kemudahan difusi ini mencegah terbentuknya tegangan lokal di dalam bahan dalam proses pemanasan. Di lain pihak, para peneliti ini mengamati ketiadaan jaringan pori-pori halus dengan interkoneksi yang ekstensif dalam sampel geopolimer metakaolin. Struktur demikian diduga kurang memungkinkan difusi uap air secara lancar dalam pemanasan. Ekspansi uap air yang tidak mampu berdifusi ke permukaan eksternal sampel inilah yang menimbulkan retakan-retakan di dalam 
sampel dan menurunkan kekuatan mekaniknya (Kong dkk., 2007). Pembandingan Gambar 2.a dengan 3.a mendukung hipotesis dari Kong dkk. (2007). Mikrostruktur mortar geopolimer metakaolin sebelum pemanasan memang dicirikan oleh jaringan pori dengan interkoneksi yang baik, namun interkoneksi pori-pori ini tidak bertahan dalam pemanasan, yang justru mempercepat konversi sisa-sisa fasa metakaolin menjadi fasa-fasa kristalin lainnya. Hal ini mengisyaratkan pula bahwa reaksi geopolimerisasi metakaolin masih cukup jauh dari ketuntasan, sehingga kuantitas metakaolin yang terkonversi menjadi mulit dan/atau nepheline dalam pemanasan masih relatif besar.

\section{KESIMPULAN}

Selain menghasilkan waktu ikat dan kuat tekan geopolimer yang lebih baik daripada metakaolin yang diproduksi dari kaolin Belitung, abu terbang dari PLTU Paiton juga menghasilkan mortar geopolimer dengan daya tahan termal yang lebih baik. Pemanasan mortar pada temperatur $800{ }^{\circ} \mathrm{C}$, yang diharapkan dapat mewakili pemaparan panas karena kejadian kebakaran pada konstruksi sipil, menyebabkan penurunan kuat tekan mortar geopolimer metakaolin secara drastis, namun justru sedikit meningkatkan kuat tekan mortar geopolimer abu terbang. Telaahan mikrostruktur dengan metode SEM menunjukkan reaksi kristalisasi mulit maupun fasa-fasa kristalin lainnya secara ekstensif pada geopolimer metakaolin, yang mengkonsumsi fasa gel geopolimer, sehingga merusak struktur jaringan gel geopolimer. Pemanasan geopolimer abu terbang menuntaskan reaksi geopolimerisasi yang meningkatkan kohesi antar partikel abu terbang dan interkoneksivitas jaringan geopolimer.

\section{DAFTAR PUSTAKA}

Barbosa, V. F. F.; MacKenzie, K. J. D., Thermal behavior of inorganic geopolymers and composites derived from sodium polysialate, Materials Research Bulletin, 2003, 38(2), 319331.

Davidovits, J., High-alkali cements for 21st century concretes, Proceedings of Mohan Malhotra Symposium on Concrete Technology: Past, Present And Future, Berkeley, 3 November 1993.
Davidovits, J., Properties of geopolymer cements, 1st International Conference on Alkaline Cements and Concretes, Kiev, Ukraine, 11-14 Oktober 1994a, hlm. 131-149.

Davidovits, J., Global warming impact on the cement and aggregates industries, World Resource Review, 1994b, 6(2), 263-278.

Davidovits, J., Chemistry of Geopolymeric Systems, Terminology, $2^{\text {nd }}$ International Conference on Geopolymers, Saint-Quentin, France, 30 Juni \& 1-2 Juli 1999.

Hilman, M. (ed.), Indonesia Second National Communication under the United Nations Framework Convention on Climate Change (UNFCCC), Republic of Indonesia Ministry of Environment, 2010.

Kong, D. L. Y.; Sanjayan, J. G.; Sagoe-Crentsil, K., Comparative performance of geopolymers made with metakaolin and fly ash after exposure to elevated temperatures, Cement and Concrete Research, 2007, 37(12), 15831589.

McCaffrey, R., Climate change and the cement industry, Global Cement and Lime Magazine (Environmental Special Issue), 2002, 15-19.

Phair, J. W.; van Deventer, J. S. J., Effect of silicate activator $\mathrm{pH}$ on the leaching and material characteristics of waste-based inorganic polymers, Minerals Engineering, 2001, 14(3), 289-304.

Phair, J. W.; van Deventer, J. S. J., Effect of the silicate activator $\mathrm{pH}$ on the microstructural characteristics of waste-based geopolymers, International Journal of Mineral Processing, 2002, 66(1-4), 121-143.

Samadhi, T. W.; Pratama, P. P., Synthesis of Geopolymer from Indonesian Kaolin and Fly Ash as a Green Construction Material, AUN/SEED-Net Regional Conference on Chemical Engineering, Pattaya, Thailand, 7-8 February 2013.

Samadhi, T. W.; Subagjo; Lismana, K. R.; Fuadi, K., Synthesis of $\gamma-\mathrm{Al}_{2} \mathrm{O}_{3}$ catalyst support from kaolin of indonesian origin, ITB Journal of Engineering Science, 2011, 43(2), 113-126. 
Pembuatan Geopolimer dari Metakaolin dan Abu Terbang (T.W. Samadhi dan P.P. Pratama)

Silva, F. J.; Thaumaturgo, C., The Chemistry, Reinforcement and Fracture in Geopolymeric Cement Composites, Proceedings of the 11th International Congress on the Chemistry of Cement, Durban, South Africa, 2003, 13791387.

Wang, M. R.; Jia, D. C.; He, P. G.; Zhou, Y., Microstructural and mechanical characteri- zation of fly ash cenosphere / metakaolinbased geopolymeric composites, Ceramics International, 2011, 37(5), 1661-1666.

Xu, H.; van Deventer, J. S. J., Effect of source materials on geopolymerization, Industrial \& Engineering Chemistry Research, 2003, 42(8), 1698-1706. 